Article

\title{
Christian Conversion, the Double Consciousness, and Transcendentalist Religious Rhetoric
}

\author{
Alan Hodder \\ Humanities, Arts, and Cultural Studies, Hampshire College, 893 West Street, Amherst, MA 01002, USA; \\ adhHA@hampshire.edu
}

Received: 13 June 2017; Accepted: 18 August 2017; Published: 24 August 2017

\begin{abstract}
Despite the theological gulf that separated the Transcendentalists from their Puritan predecessors, certain leading Transcendentalists-Emerson, Fuller, and Thoreau among them-often punctuated their writings, published and private, with literary representations of dramatic episodes of spiritual awakening whose rhetorical structure sometimes betrays suggestive parallels with traditional, recognizably Christian, forms of conversion rhetoric. While all of these Transcendentalists clearly showcase representations of dramatic religious experience in their work, this reliance on Christian rhetorical patterns is most obvious in the early writings of Emerson and Fuller. Thoreau's constructions reflect little ostensible Christian influence, yet even here, thematic continuities with earlier forms of religious self-expression are discernible.
\end{abstract}

Keywords: Transcendentalism; religious experience; religious rhetoric; William James; Ralph Waldo Emerson; Jones Very; Margaret Fuller; Henry David Thoreau

\section{Introduction}

In the December 1940 issue of The New England Quarterly there appeared for the first time Perry Miller's famous and famously controversial essay, "From Edwards to Emerson." Here, extending the implications of his monumental research on New England Puritanism, Miller posited an essential religious continuity between the work of Jonathan Edwards and Ralph Waldo Emerson-a remarkable claim considering the profound alterations that had occurred in the American religious and political landscape over the course of the intervening century. Summing up his argument in the closing paragraph of the essay, Miller wrote: "From the time of Edwards to that of Emerson, the husks of Puritanism were being discarded, but the energies of many Puritans were not yet diverted-they could not be diverted-from a passionate search of the soul and of nature, from the quest to which Calvinism had devoted them. These New Englanders-a few here and there-turned aside from the doctrines of sin and predestination, and thereupon sought with renewed fervor for the accents of the Holy Ghost in their own hearts and in woods and mountains" (Miller 1956).

Even in its own time this essay clearly raised some eyebrows, particularly among those critics skeptical of its apparently sweeping historical claims, so much so that when Miller decided to include it in his 1956 collection of essays, Errand into the Wilderness, he attached a disclaimer in the form of an extended headnote. There he acknowledged the consternation with which his essay had initially been greeted but rejected the notion that "in some mystical pretension" he had meant to argue for a "direct line of intellectual descent." From a strictly historical point of view, he conceded, there was "no organic evolution of ideas from Edwards to Emerson," and confessed that "for a while, I regretted ever having published this speculation." But once having clarified the sorts of connections he emphatically had not intended, Miller then doubled down on his basic thesis: "What is persistent, from the covenant theology (and from the heretics against the covenant) to Edwards and to Emerson is the Puritan's effort to confront, face-to-face, the image of a blinding divinity in the physical universe, and to look 
upon that universe without the intermediacy of ritual, of ceremony, of the Mass and the confessional" (Miller 1956, pp. 184-85).

Miller's depiction of Emerson and other Transcendentalists in such starkly Augustinian-and even Edwardsean-terms may have been intended as a critical corrective to Parrington's then hugely influential construction of Emerson as a social critic or Van Wyck Brooks' conception of him as a benign poet-naturalist, but most religious and literary historians since then have found it too vague or impressionistic to be completely useful (Parrington 1927; Brooks 1936). To many, the claim for an essential religious continuity between the Puritans and the Transcendentalists on historical or theological grounds seemed farfetched. Instead, they were more inclined to turn their attention to clearly documentable religious and historical connections, in particular the obvious embeddedness of the Transcendentalist Movement in the early nineteenth-century Unitarian culture of eastern Massachusetts (Hutchison 1959; Howe 1970; Robinson 1982). This made complete sense, since as Dean Grodzins has recently reminded us, virtually every participant in the Movement, women and men alike, had been affiliated at some point in their lives with the New England Unitarian churches (Grodzins 2010). Many of the leading male participants were, in fact, Unitarian ministers, or at least friends and colleagues of Unitarian ministers, and most had been educated at Harvard or, as in the case of Margaret Fuller and other female participants, under the intellectual aegis of Harvard. These young ministers and intellectuals thus affirmed the same theological values, looked to the same religious models, read many of the same books and journals, and generally thrived in the same openly liberal religious and cultural atmosphere fostered by the Unitarian community of eastern Massachusetts (Packer 2007; Gura 2007).

Despite this general reorientation to the Unitarian foundations of Transcendentalism among most scholars, a few have sometimes returned to Miller's thesis in considering what they understand to be the Puritan precedents of later expressions of American culture (Hodder 1991, pp. 423-46). In what follows, I would like to revisit his thesis also-not in order to defend Miller's argument in total, but to use it as a critical point of departure for a consideration of certain features of Transcendentalist religious sensibility and literary style that cannot be so easily explained within a more localized Unitarian religious context, or at least what we have come to see as the normative Unitarian religious context of the 1830s and 40s. My thesis is that, despite the obvious theological and cultural gulf that separated the Transcendentalists from their New England Puritan predecessors, certain leading Transcendentalists-Emerson, Fuller, and Thoreau among them-exhibited in their journals and other private writings a surprisingly strong interest in and apparent familiarity with dramatic episodes of spiritual awakening, which they represented in their published writings in the form of various noteworthy, and often memorable, Transcendentalist epiphanies whose rhetorical structure often betrays suggestive parallels with traditional—recognizably Christian—forms of conversion rhetoric.

Just as traditional Christian notions of religious conversion turned essentially on a two-stage movement from sin to righteousness, self-denial to faith, so also Transcendentalist epiphanies often depict spiritual awakening in terms of a two-part movement from self-emptying or self-transparency to spiritual fullness, which Emerson, and following him Thoreau, sometimes connoted by such terms as "ecstasy" or "the double consciousness." While all three of these Transcendentalists clearly showcase representations of dramatic spiritual experience in their work, this reliance on such a basic Christian rhetorical pattern is most obvious in the early writings of Emerson and Fuller. Thoreau's constructions of this sort, on the other hand, reflect little traditional Christian influence, and seem on their face more experimental and even, from a literary standpoint, more eccentric. Yet, even in his case, certain thematic continuities with earlier forms of religious self-expression, particularly his various depictions of self-transparency, are discernible. Sometimes such Transcendentalist literary representations are demonstrably grounded in personal experience, but whether personal or simply imaginative and rhetorical, this preoccupation with powerful and immediate religious inspiration, conceived as a dramatic, revelatory movement from emptiness to spiritual fullness, harked back to an earlier era, thus distinguishing these Transcendentalists from those within the main Unitarian religious establishment. 


\section{Religious and Historical Context}

As Conrad Wright long ago pointed out, doctrinally speaking, the eighteenth-century liberal movement that eventually gave rise to New England Unitarianism was characterized by three distinguishable theological trends: Arminianism, supernatural rationalism, and anti-Trinitarianism (Wright 1955). One of the chief historical catalysts for the development of theological liberalism, however, was the discomfiture of a number of ministers of eastern Massachusetts with what they regarded as the emotional excesses of the revivals of the 1730s and 40s during the Great Awakening. Jonathan Edwards, the recognized leader of the Awakening in the Connecticut River Valley, famously defended the revival in a series of circumspect and measured letters and treatises. But some liberal-tending ministers were clearly less sanguine about the value and authenticity of this seemingly ungovernable outpouring of religious passion. Charles Chauncy, a leading critic of Awakening enthusiasm, inveighed against what he regarded as the indecorous elevation of religious feeling as the work of the Devil, arguing that "An enlightened Mind, and not raised Affections, ought always to be the Guide of those who call themselves men; and this, in the Affairs of Religion, as well as other things" (Howe 1970; Chauncy 1743).

Up until this point in history, few in the New England Puritan community would have questioned the traditional Puritan conception of conversion as a dramatic and often relatively sudden in-breaking of divine grace and concomitant transformation of character. First-generation ministers preached about conversion repeatedly, especially in their Sunday sermons, and sometimes dissected the stages of the Way of Salvation (ordo salutis) at great length and in labyrinthine detail. Conversion was clearly, from the Calvinist point of view, the very crux of the Christian life-at least in theory-and this despite the fact that in practice the sort of dramatic conversions extolled by New England's first ministers had apparently become increasingly less familiar among their second- and third-generation descendants, a circumstance that had dramatic repercussions on both the polity and preaching of the Puritan community in the mid-seventeenth century and after.

While Chauncy's lengthy critique focused on the evident subordination of reason to religious feeling amid the throes of religious enthusiasm during the Great Awakening, it also effectively struck at the heart of traditional Puritan piety. When the religious and social upheavals of the 1740 s finally subsided, ministers disillusioned with the revivals increasingly viewed traditional conceptions of conversion with growing wariness, and by the early years of the nineteenth century, with the consolidation of liberal ideals under the new banner of Unitarianism, liberals of eastern Massachusetts for the most part rejected evangelical models of Christian conversion altogether, espousing instead a conception of conversion as a much more gradual, life-long molding of human character (Howe 1970, pp. 116-20). No one better typifies this new attitude to conversion than William Ellery Channing himself, the widely admired leader of the Unitarian Movement, whose preaching effectively abandoned the older notions of sudden conversion in favor of a life-long commitment to the development of Christian humility, virtue, and reasonableness.

That having been said, it would be misleading and historically anachronistic to suggest that even the most liberal Unitarians and Transcendentalists would have been necessarily unfamiliar with or adamantly opposed to conversion-based religion. This was the period, after all, of the Second Great Awakening, and religious revivalism was once again on the rise in New England, as it was abundantly elsewhere throughout the early decades of the nineteenth century. Even Unitarian Boston felt the repercussions of revivalist preaching. Not long before Emerson took up his responsibilities as the pastor of Boston's Second Church, the Calvinist preacher Lyman Beecher, one of the revival's leaders in New England, decided to make the Hanover Street Church, just down the block from Emerson's own church, the base for his ferocious attack on Boston's liberal ecclesiastical establishment. The truth is that however much mainstream Unitarianism had turned away from the fervency of conversion-centered religion, it was still a part of the traditional fabric of New England religious culture-in the large towns as well as in the countryside - and still alive in family lore and traditions, if not the personal experience of some in the liberal community itself. 
For a vivid illustration of this Puritan afterglow even in Unitarian Boston, we need look no further than the example of Emerson himself. Emerson admired the robust spirituality of his Puritan forebears and appreciated the hold it continued to have on the hearts and minds of his New England contemporaries. "What a debt is ours," he wrote in 1841, "to that old religion which in the childhood of most of us, still dwelt like a sabbath morning in the country of New England, teaching privation, self-denial and sorrow! A man was born not for prosperity, but to suffer for the benefit of others, like the noble rock-maple which all around our villages bleeds for the service of man" (Emerson 1971, vol. 1, p. 135). Emerson was descended after all from a long line of Puritan ministers-on both sides of his family—who had, until recent decades, still subscribed to the old Calvinist creeds. Ezra Ripley, Emerson's religiously conservative step-grandfather, ministered to the First Parish Church of Concord for some sixty years in ways that harked back to an earlier era. And while Emerson had little regard for the theological formulas of by-gone evangelical preaching, he had great admiration for the charismatic evangelical preacher Edward Taylor (the model for Melville's "Father Mapple" in Moby Dick) who served at a chapel for sailors in Boston (Emerson 1965, vol. 5, p. 287; vol. 9, pp. 233-35). Indeed, for an exemplar of some of the values and virtues of the old-time religion, Emerson need only look to his own beloved aunt, Mary Moody Emerson, who despite her fierce intellectual independence and progressive questing spirit, also exhibited the tough-minded virtues of the older New England faith and who served throughout his youth and young adulthood as both mentor and muse (Cole 2002). Some of Emerson's own sermons and many of his earliest journal entries characteristically exhibit traces of the older prophetic and apocalyptic sensibility, a fact he was apt to credit to the influence of his aunt. "In my childhood," Emerson wrote in 1837, "Aunt Mary herself wrote the prayers which first my brother William and when he went to college I read aloud morning and evening at the family devotions, and they still sound in my ear with their prophetic and apocalyptic ejaculations" (Emerson 1965, vol. 5, pp. 323-24).

Furthermore, notwithstanding the schism between Unitarians and Congregationalists that had divided so many churches of eastern Massachusetts in the early years of the nineteenth century, it would be a mistake to impute a great deal of uniformity, either in theology or worship, to the liberal churches of the period. Even among Transcendentalist ministers, there was much diversity of opinion, ranging from James Freeman Clarke, who continued to conceived of himself in Christian terms throughout his long career, to Emerson and Theodore Parker, whose radical theological and ecclesiastical views quickly carried them beyond the pale of the Christian churches altogether. To say that the Unitarian clerical establishment as a whole had become unsympathetic to conversion traditionally conceived is not to say that these ministers were indifferent to the importance of cultivating religious feeling or even evangelically inspired religious fervency. On the contrary, as Daniel Walker Howe showed long ago, the Unitarian community included several prominent ministers who warmly espoused the importance of a "religion of the heart," even within the scholastic precincts of Harvard College and the Divinity School. Among these was the young John Emery Abbot, an exemplar of Unitarian pietism, who preached a gospel of devotional asceticism in Salem's North Church for several years before his early death in 1819 .

More consequential for our purposes, however, was Henry Ware Jr., Emerson's predecessor at Boston's Second Church. Like Abbot, Ware exemplified the pietist strain of early Unitarianism, championing an approach to preaching and pastoral work that blended theological liberalism with a strong appeal to religious emotions, devotion, and self-surrender. During his almost 10 years ministering to the Second Church, Ware successfully presided over what Howe calls "one of the most remarkable religious awakenings among the Unitarian churches of Boston" (Howe 1970, p. 165). When Ware resigned his ministerial post due to ill health in 1828, he accepted an appointment at Harvard's Divinity School as the first Professor of Pulpit Eloquence and Pastoral Care, from which position he helped to inspire the next generation of Unitarian ministers, including some who would later identify themselves as Transcendentalists (Howe 1970). 


\section{Jones Very: Emerson's “Brave Saint"}

One of the most noteworthy of these was the young Jones Very, whose often-remarked religious crisis vividly exemplified this pietist strain of Unitarian observance, as well as the continuing role of sudden, life-changing religious conversion, even within such theologically liberal religious circles. To be clear, Very was not a Transcendentalist in any obvious philosophical or doctrinal sense, but he moved for a time in Transcendentalist social circles and as a young man received warm support from the likes of Elizabeth Peabody, Bronson Alcott, James Freeman Clarke, and Emerson himself (Deese 1993; Gittleman 1967). According to his own reckoning, Very understood this early life crisis entirely and exclusively in traditional religious terms as a Christian conversion experience-a "new birth" as he termed it-and he recounted it in meticulous and explicit detail. As such, it provides an instructive touchstone and point of reference for the more displaced literary representations of the Transcendentalists to whom we will turn next.

Very was born in Salem, Massachusetts, in 1813, the son of an atheistic, free-thinking mother and a mostly absent ship's captain who died when Very was only 11 years old. The family was not well off, but Jones managed to scrape together enough money from teaching to enroll at Harvard College, where he matriculated as a sophomore in the fall of 1833. Upon his arrival in Cambridge, Very soon distinguished himself as one of his class's most accomplished Classics scholars and a poet of exceptional promise. By the end of his first year, he was already sending out poems for publication in his hometown newspaper, the Salem Observer, and by the time of his graduation, he had published some forty poems and been twice awarded the College's coveted Bowdoin Prize. In June of 1836, Very graduated second in his class at Harvard and, in recognition of his remarkable academic achievement, was appointed to the post of Tutor in Greek beginning the following fall.

Beginning in his second year at Harvard, Very's religious faith had grown increasingly more fervent. He soon joined Ware's Society for Religious Improvement, a Unitarian religious group dedicated to the spiritual welfare of Harvard's students, and he began actively counseling other students. By the time Very took up his responsibilities as a Harvard tutor, his sense of religious vocation had become the driving force of his life, and he began setting his sights on a career in the ministry. Over the course of the next two years, he devoted himself to his students, but his mentoring was now motivated as much by evangelical as by scholarly concerns.

By the fall of 1838, a few weeks into the new semester, the tide of Very's religious enthusiasm rose to such heights as to leave him temporarily unmoored. Students showed up to meetings with him only to find their beloved tutor quite beside himself, professing apocalyptic declarations and manic oracular revelations. To his mentor, Henry Ware Jr., Very privately affirmed that he had now "given up his own will and ... only did the will of the Father." The next day he exhorted the students in his Greek class to "flee to the mountains, for the end of all things is at hand." Needless to say, students were left nonplussed and unsettled by their tutor's strange behavior, and on hearing the reports, the College's president Josiah Quincy quickly terminated Very's appointment and the next day had him escorted home to Salem. The following morning, Very showed up unannounced at the home of Elizabeth Peabody, a supporter and leading light of the new Transcendentalist movement, to whom he solemnly declared himself an incarnation of the Second Coming. All this was too much for the local authorities, who soon after had Very committed to McLean's Asylum in Charlestown. There Very spent the next month under close observation.

Shortly after Very's release from McLean's, Emerson received a note from Peabody, warning him that Very was on his way to Concord to pay him a visit. Emerson, who had attended one of Very's lectures at the Concord Lyceum the previous April and thought highly of the young scholar, had been shocked to hear of his unfortunate transformation, but received him warmly nevertheless when he turned up at his door a few days later. Emerson must obviously have recognized Very's precarious mental state, but invited him to stay at his family's home for the next five days anyway. In the course of the visit, Emerson came to appreciate the sincerity, even perhaps the authenticity, of Very's prophetic charisma, dubbing him "our brave saint" (Emerson 1965, vol. 7, pp. 127-28). When Very left, Emerson 
wrote back to Peabody, summarizing the visit and concluding that, notwithstanding the evident mania, on some level the young man was "profoundly sane" (Emerson 1939, vol. 7, p. 325). In his journal, Emerson went even further: "And he is gone into the multitude as solitary as Jesus. In dismissing him I seem to have discharged an arrow into the heart of society. Wherever that young enthusiast goes he will astonish \& disconcert men by dividing for them the cloud that covers the profound gulf that is in man" (Emerson 1965, vol. 7, p. 123). Very's religious transport continued for some eighteen months, during which time he produced some three hundred remarkable poems, sometimes at the rate of several per week (Deese 1993).

For his part, Very obviously conceived this period of his life in more or less normative Christian terms. As Helen Deese documents, while still in the early throes of his religious transport, Very offered his own coherent account of what was happening to him in a letter to Henry Bellows, one of his former students: "You probably heard rumors in relation to my leaving Cambridge the truth of which I am now to testify. From what you knew of me before you are aware that my effort was ever to purify my soul and that I was so led by suffering to make this my constant work. In my senior year in college I experienced what is commonly called a change of heart, which tells us that all we have belongs to God and that we ought to have no will of our own" (Deese 1993, p. lvi, his italics). The phrase "change of heart" is obviously not Very's own invention; he is drawing on traditional Protestant theological language. It is reminiscent of Edwards' notion of "the sense of the heart," and like Edwards, Very understands it as a function of the will. This subjugation of the personal will in accordance with God's will is what precipitated the "new birth" that followed.

While Very's retrospective account reflected the intensity of the actual experience, it was not noticeably idiosyncratic. It provided a remarkable instance, in subject and form, of a kind of Unitarian conversion narrative, while at several points reflected more traditional theological language and older New England conceptions of the way of salvation. After undergoing a "change of heart" in his senior year, Very then conceived his subsequent conversion experience as consisting essentially of three stages. The first, a phase of purgation, was characterized by an ongoing internal struggle with "temptation" to which he was "continually prone" and against which he "continually strove." This then led at the end of his second year to a period reconciliation and of disinterested engagement in activity that resulted in "much peace and content." This intermediary state of peace and reconciliation finally culminated, at the start of his third year, in a state of complete surrender to the higher will. When this awareness first dawned, it was accompanied by a sense of "two consciousnesses," but these too, he wrote, eventually melded into one in which his natural impulses became completely identified with the movement of the Spirit. Here in Very's own words is how he recounts this culminating phase of his experience:

\begin{abstract}
After having begun my duties at Cambridge this year about the third week I felt within me a new will something which came some time in the week but I could not tell what day exactly. It seemed like my old will only it was to the good-it was not a feeling of my own but a sensible will that was not my own. Accompanying this was another feeling as it were a consciousness which seemed to say- "That which creates you creates also that which you see or him to whom you speak," as it might be. These two consciousnesses as I may call them continued with me two or three weeks and went as they came imperceptably [sic]. While they continued I was moved entirely by the Spirit within me to declare to all that the coming of Christ was at Hand ... The changes which I there passed through and have since known are such as every one born of God must experience they are within and lead on from glory to glory. I now know by the Spirit of God that my former change that which is commonly called the new birth, was but the hearing of the voice of John in the wilderness of my heart, and that the purification I experienced, in obeying him, in cutting down the corrupt tree and preparing the way for the One who came after was that of his baptism of water... (Deese 1993, pp. lvi-lviii).
\end{abstract}

Very's narrative may not conform in strictness to any particular seventeenth-century morphology of conversion, but it reflects clear family resemblances. To say so is not to dredge up older arguments 
that Very was at heart a Calvinist. He was clearly not, but remained then, and throughout his later life as a minister, what he called a "Channing Unitarian." Indeed, as we have seen, one need not go outside of the Unitarian fold to locate the sources of Very's religious self-understanding (Robinson 1975).

One of the first literary fruits of Very's period of religious fervor appeared in the Salem Observer in late October while Very was still visiting the Emerson home. The poem, a sonnet entitled "The New Birth," offered a vivid lyrical representation of his recent religious awakening, and apart from its dramatic intensity, there was nothing, from a formal or thematic standpoint, deranged about it. The meter and rhyme scheme are regular, and the three quatrains build to an effective climax.

'Tis a new life-thoughts move not as they did

With slow uncertain steps across my mind,

In thronging haste fast pressing on they bid

The portals open to the viewless wind;

That comes not, save when in the dust is laid

The crown of pride that gilds each mortal brow,

And from before man's vision melting fade

The heavens and earth-Their walls are falling now-

Fast crowding on each thought claims utterance strong,

Storm-lifted waves swift rushing to the shore

On from the sea they send their shouts along,

Back through the cave-worn rocks their thunders roar,

And I a child of god by Christ made free

Start from death's slumber to eternity. (Very 1993, p. 64).

This poetic representation of Very's spiritual rebirth echoes the more prosaic account to Bellows in several respects, but it essentializes, and in so doing dramatizes, its basic experiential structure. The poem's argument turns essentially on a movement from pride to selflessness, uncertainty to assurance, death to eternal life, in a way entirely characteristic of traditional Puritan and Christian conversion rhetoric. The presiding trope of rebirth is of course grounded in gospel teaching (John 3:3), and the image of the concomitant falling away of "the heavens and earth" raises the religious significance of this transformation to apocalyptic heights. By the same token, the sea and seashore imagery place the religious drama in a more familiar naturalistic, if not Romantic, setting. When later that fall, Emerson for the first time read two of the sonnets that Very had sent him, he was so impressed that he quickly wrote back praising the young poet's work and asking him to consider putting together a collection of prose and poetry that Emerson himself would help to see through to publication (Emerson 1939, vol. 7, p. 326).

In retrospect, it may be hard to square Jones Very's committedly Christian orientation with our usual conceptions of Emersonian Transcendentalism, given the apparently sharp disjunction between Very's religious orientation and Emerson's. Yet surprisingly enough, many of the Transcendentalists who knew Very, Emerson not least, approved of his vividly experiential spirituality, at least in principle, and found no difficulty in according to it genuine religious authority (Deese 1993, pp. xxiii-xxvii). Very's example thus serves as an instructive touchstone, since it dramatizes how proximate, even how familiar, traditional patterns of Christian faith continued to be for young Unitarian liberals-including the Transcendentalists—-within the antebellum New England scene.

\section{From Edwards to Emerson}

Emerson's extraordinarily charitable reception of Very's religious witnessing, and subsequently his poems, presumably reflects in part his previous pastoral experience and in part his well-attested generosity to younger scholars and writers. That being said, it is also tempting to speculate that Emerson's warm regard for Very, as well as his affirming comments about his religious experiences, may have had something to do with the importance of similar experiences in Emerson's own life. 
Of course, from a formal theological standpoint, Emerson mainly conceived religious conversion-as most of his Unitarian colleagues did-in gradualist terms as a progressive transformation of character, but that apparently did not mean that he would deny the existence of such experiences outright or dispute their power when they occurred.

Perhaps the principal analogue for such a conversion in Emerson's own life was the powerful religious awakening that occurred in the summer of 1831, several months after the death of his first wife, Ellen Tucker Emerson. The most dramatic literary expression of this awakening was the oracular poem, entitled "Gnothi Seauton" ("Know Thyself"), which Emerson drafted into his journal on 6 July 1831. Here Emerson highlights the crux of his realization with the proclamation that "God dwells in thee" (Emerson 1965, vol. 3, pp. 290-95). At this point, the insight of God's eternal presence in the human soul clearly struck Emerson with the force of revelation, and from this point forward, his journals reverberate with various iterations of this theme. In a sermon preached soon after his return from Europe two years later, he proclaimed:

Man begins to hear a voice ... that fills the heavens and the earth, saying, that God is within him, that there is the celestial host. I find that this amazing revelation of my immediate relation to God, is a solution to all the doubts that oppressed me. I recognize the distinction of the outer and the inner self, - of the double consciousness, - . . that is, there are two selfs, one which does or approves that which the other does not and approves not; or within this erring, passionate, mortal self, sits a supreme, calm immortal mind, whose powers I do not know, but it is stronger than I am, it is wiser than I am ... (Emerson 1992, vol. 4, pp. 215).

The phrase "double consciousness," which Emerson invokes here, acquired increasing philosophical currency over the course of the next several years in his early lectures and essays. In the lecture entitled "The Transcendentalist," which he presented in Boston in 1841, he invokes the phrase once again, this time to distinguish between the mundane life of the "understanding" and the infinite life of the "soul" (Emerson 1971, vol. 1, p. 213). At this point in his career, the notion of the double consciousness helped to underwrite the key Coleridgean distinction between understanding and Reason, but both here and in the sermon of 1833 cited above, it also clearly had a religious, even an experiential, significance reminiscent of Very's description of the "two consciousnesses" that he experienced at the penultimate point of his conversion.

Indeed, Emerson was apparently no stranger to more abrupt episodes of religious transport of the sort that Jones Very had experienced in 1838. One such episode occurred during a visit to the Mount Auburn Cemetery in Cambridge in the spring of 1834 (Emerson 1965, vol. 4, p. 273). Another may well have provided the experiential basis for the famous epiphany of the transparent eyeball that opens Nature. Throughout Emerson's writings, early and late, readers periodically come across literary passages that suggest experiences of peculiar intensity and power to which he was apparently subject, experiences to which he sometimes gave the designation "ecstasy," a term whose literal sense - "to stand outside oneself" - certainly provided a fitting experiential counterpart to the more formal theological notion of the double consciousness (Richardson 1995, pp. 349-54). It was apparently this sort of experience to which Emerson alluded when in his journal of 1841, he asserted that what distinguished his own faith from that of others was just such episodes of transitory religious ecstasy: "It is not to be denied," he wrote, "that there is this wide difference between my faith \& other faith, that mine is some brief affecting experience which surprised me on the highway or in the market place-in some place at some time whether in the body or out of the body, I cannot tell, God knoweth, - \& made me aware that I had played the fool with fools all this time, but that there was, for me \& for all,- - law, and ineffable sweetness of childlike carriage - and I should never be fool more ... (Emerson 1965, vol. 8, pp. 98-99).

It is interesting-and noteworthy for the light it sheds on the sources of Emerson's spiritual self-understanding - that in citing these pivotal religious experiences here, Emerson should quote Paul's famous account of being "caught up" ecstatically to the third heaven in his second letter to the Corinthians (2 Cor. 12:2). By the same token, it is also crucial to acknowledge that, in contrast to Paul 
or to Very's descriptions or to the conversion narratives of Puritan tradition, Emerson's mature literary representations did not typically designate Christ as the source of personal transformation or the ground of the soul; it was rather the transcendental "Self" or "Oversoul" or "Spirit" that assumed this office. In identifying Christian echoes in the writings of Emerson and several of his most like-minded colleagues, we obviously need to look beyond the diverging religious or theological substance to matters of literary construction and form. After all, the links between the literary representations of Emerson on the one hand and those of Very, Edwards, or the Puritans on the other were comprised not of shared creedal substance but rather the verbal form in which these religious experiences were cast.

Whatever one may think about Perry Miller's claims for a religious continuity between Edwards and Emerson, literary analysis at least suggests some rather striking rhetorical parallels in their writing. Transcendental prose and poetry is rife with the literary device known as epiphany, and perhaps the most famous example is the one, alluded to above, which Emerson stages in the opening pages of Nature, his first book:

Crossing a bare common, in snow puddles, at twilight, under a clouded sky, without having in my thoughts any occurrence of special good fortune, I have enjoyed a perfect exhilaration. I am glad to the brink of fear. In the woods, too, a man casts off his years, as the snake his slough, and at what period soever of life is always a child. In the woods is perpetual youth ... Standing on the bare ground,- - my head bathed by the blithe air and uplifted into infinite space,-all mean egotism vanishes. I become a transparent eyeball; I am nothing; I see all; the currents of the Universal Being circulate through me; I am part or parcel of God. (Emerson 1957, p. 24).

Since the time of Christopher Cranch's funny lampoon of this passage, Emerson's readers have tended to focus on the uncouth image of the transparent eyeball. But in doing so, they often neglect to note this famous passage's general indebtedness to Puritan conversion rhetoric. Here, for the sake of illustration, is a similar account from Jonathan Edwards' own conversion narrative, the "Personal Narrative," produced almost a hundred years before:

There was no part of creature-holiness, that I then, and at other times, had so great a sense of the loveliness of, as humility, brokenness of heart and poverty of spirit: and there was nothing that I had such a spirit to long for. My heart as it were panted after this, to lie low before God, and in the dust; that I might be nothing, and that God might be all; that I might become as a little child. (Edwards 1995, p. 288).

The juxtaposition of these two passages certainly reflects different religious values and sensibilities, but it is hard not to be struck by the foregrounding of the gospel-based childhood theme in both, and the essential coincidence of syntax and style—in particular Edwards' "I might be nothing, and that God might be all" and Emerson's "I am nothing; I see all ... I am part or parcel of God." Whether the source of religious inspiration is conceived as the Holy Spirit, as in Edwards, or the transpersonal "Self" or "Oversoul," as in Emerson, the revelation essentially turns on the movement from emptiness to fullness, from a vanquishing of lower self to an afflatus of the Absolute. The subject in both representations does not achieve divine inspiration by a process of being puffed up unless and until he is utterly emptied and deflated. And as peculiar as Emerson's imagery may seem in certain respects, he continued to stress the importance of such self-abnegation and self-abandonment in various essays and addresses throughout the next 10 years. In his address "Literary Ethics," which he delivered at Dartmouth College two years later, he struck this note in a way that, once again, clearly called up the older forms of Puritan piety:

Then accept the hint of shame, of spiritual emptiness and waste, which true Nature gives you, and retire, and hide; lock the door; shut the shutters; then welcome falls the imprisoning rain,- - dear hermitage of nature. Re-collect the spirits. Have solitary prayer 
and praise. Digest and correct the past experience. Blend it with the new and divine life, and grow with God. (Emerson 1971, vol. 1, p. 110).

The culmination of Emerson's literary representations of this new Transcendentalist faith, however, was of course his essay "Self-Reliance," arguably the nation's most famous-and famously contested-essay, which appeared in his first collection of essays in 1841. More traditionally-minded readers in Emerson's own day condemned this essay, along with others contained in this volume, as throwing open the door to narcissism and antinomianism. Even Mary Moody Emerson herself, who until this point in Waldo's career often helped to nurture her nephew's philosophical explorations, excoriated these essays as "a strange medley of atheism and false independence" (Rusk 1949, pp. 283-84). More recently, some critics have even placed the blame for modern Americans' imputed selfishness and unbridled individualism at Emerson's door (Bellah et al. 1985).

Yet a close reading of "Self-Reliance" suggests that it is not the godless, narcissistic declaration it is sometimes taken to be, but actually rife with references to God and divine inspiration. Gone of course is the older theological language of sin and grace, but religious tropes and superstructure are still very much apparent throughout. Particularly interesting for our purposes is the continued elaboration, even here in this classic Emersonian statement, of what we might term negative or apophatic theology, the representation, that is, of heightened religious experience by way of negation and exclusion. What we tend to remember from this essay, however, are those passages extolling in affirmative language the advent of the "aboriginal Self," as in the following evocative formulation from the mid-portion of the essay:

For the sense of being which in calm hours rises, we know not how, in the soul, is not diverse from things, from space, from light, from time, from man, but one with them, and proceeds obviously from the same source whence their life and being also proceed. We first share the life by which things exist, and afterwards see them as appearances in nature, and forget that we have shared their cause. Here is the fountain of action and of thought. Here are the lungs of that inspiration which giveth man wisdom, and which cannot be denied without impiety and atheism. We lie in the lap of immense intelligence, which makes us receivers of its truth and organs of its activity. When we discern justice, when we discern truth, we do nothing of ourselves, but allow a passage to its beams. (Emerson 1971, vol. 2, p. 37).

In theological terms, the language of this passage is vividly cataphatic or attributive in its reliance on such dominant images as "fountain," "lungs," "beams," and so forth. Yet even here, Emerson emphasizes once again the importance of transparency and passivity: "we do nothing of ourselves, but allow a passage to its beams." Furthermore, as the essay unfolds, the affirmative language that characterizes the passage becomes increasingly supplanted by a strikingly apophatic or negative theology:

And now at last the highest truth on this subject remains unsaid; probably, cannot be said; for all that we say is the far off remembering of the intuition. That thought, by which I can now nearest approach to say it, is this. When good is near you, when you have life in yourself, it is not by any known or accustomed way; you shall not discern the foot-prints of any other; you shall not see the face of man; you shall not hear any name; - the way, the thought, the good shall be wholly strange and new. It shall exclude example and experience. You take the way from man, not to man. (Emerson 1971, vol. 2, p. 39).

Emerson's substitution here at the end of this passage of the triadic formulation- "the way, the thought, the good"-for the Gospel of John's memorable ascription of Christ as "the way and the truth and the life" (Jn. 14:6) does not so much repudiate biblical revelation as interiorize it in a way that even Edwards no doubt would appreciate. Emerson certainly drew from various springs in his representation of religious experience-Quaker, Neo-Platonist, biblical, among others-but he 
appears to have found this traditional strand of Christian apophatic theology particularly apposite for his purposes.

\section{Margaret Fuller's Religious Awakening}

To most readers, Margaret Fuller is best remembered as a groundbreaking nineteenth-century American feminist, a social reformer, a charismatic leader of the Transcendentalist Movement, an educator, and a journalist. Clearly, she played all of these roles and did so with unusual intellectual energy and personal charisma. But Fuller was also possessed of a religious personality of the deepest dye, and in many ways, this role may be key to all the others. Both her journal and her published writings reflect this religious dimension at several points and testify to the importance of religion and spirituality in her own life. And while her later religious explorations seem anything but orthodox in a traditional Christian sense, her journalistic accounts of her earliest, most formative religious experiences suggest some of the same traditionally Christian earmarks as we saw in the work of Very and Emerson, not least their emphasis on the negation and emptying of the lower self in relation to the higher Self or Spirit.

In the year 1840, at the age of thirty, Fuller wrote in her journal: "I grow more and more what they will call a mystic. Nothing interests me except listening to the secret harmonies of nature ... " (Steele 1992, p. 12). Such an avowal, had she proffered it in the first twenty years of her life, would have come as something of a surprise to her friends and family. Like Emerson, she had grown up in a respectable Unitarian milieu in the Greater Boston area, but neither of her parents was overtly religious. Proud of his Harvard scholastic training, her father, Timothy Fuller, was a regular churchgoer and stolid member of the Unitarian community, but he was mainly drawn to mainstream Unitarianism's emphasis on self-culture, rationalist inquiry, and social respectability. He had long rejected Calvinist creeds and abhorred the overt displays of religious feeling he associated with the camp meetings of Southern Methodists and Baptists. His was a steady, down-to-earth, and unperturbed form of religious observance. For her part, Margarett Crane Fuller, Fuller's mother, was more fervent in her faith than her husband, though she too shied away from religious enthusiasm and gladly embraced the rationalistic orientation of her contemporary Unitarian culture (Capper 1992, pp. 11-23). A notorious taskmaster, Margaret's father insisted on taking charge of her earliest education, with the intention apparently of reproducing in her the classical education that he himself had received at Harvard. In view of these familial influences, there was little in Margaret Fuller's early life that would portend the powerful preoccupation with religion and mysticism that characterized her later life, when as Emerson later quipped, "poetry, love, and religion" were the "cardinal points" of her conversations (Fuller 1852, vol. 1, p. 218).

Perhaps the fullest and most revealing statement we have of Fuller's early attitudes to religion are to be found in a letter she wrote at the age of twenty to her charismatic older cousin George Davis. Throughout Margaret's teenage years, Davis had served as a lively model and instigator of the fluent intellectuality, religious iconoclasm, and conversational panache to which she herself aspired. Together they explored their shared interests in various European Romantic writers, defending them against the criticisms of their staid Unitarian detractors. As a result, Fuller's earliest considered views of conventional Christian religion were somewhat disdainful and dismissive: "Loving or feeble natures need a positive religion, a visible refuge, a protection, as much in the passionate season of youth as in those stages nearer the grave. But mine is not such ... I believe in Eternal Progression. I believe in a God, a Beauty and Perfection to which I am to strive all my life for assimilation. From these two articles of belief, I draw the rules by which I strive to regulate my life. But, though I reverence all religions as necessary to the happiness of man, I am yet ignorant of the religion of Revelation. Tangible promises! well defined hopes! are things of which I do not now feel the need" (Capper 1992, p. 102). This Romantic declaration would have accorded well with the view that her friends apparently had of her at this point in her life. Emerson, in his later recollection, noted her devoted coterie of friends of 
both sexes but pointed out that her women friends described her as "a wonder of intellect, who yet had no religion (Fuller 1852, vol. 1, pp. 204-5).

All of this makes what happened the following year so unexpected and so remarkable. As Fuller later recounted in her journal, on Thanksgiving Day in the year 1831, she reluctantly agreed to attend church in Groton at the behest of her father. But she found the day dreary and the service even more jarring than usual, and she longed to escape the church, preacher, and, by implication, her domineering father as soon as possible. "I was in haste," she later wrote, "for all to be over, that I might get into the free air." Walking hurriedly across the brown lifeless fields, she paused by the side of a small stream, and here is what transpired next:

Suddenly the sun shone out with that transparent sweetness, like the last smile of a dying lover, which it will use when it has been unkind all a cold autumn day. And, even then, passed into my thought a beam from its true sun, from its native sphere, which has never since departed from me. I remembered how, a little child, I had stopped myself one day on the stairs, and asked, how came I here? How is it that I seem to be this Margaret Fuller? What does it mean? What shall I do about it? I remembered all the times and ways in which the same thought had returned. I saw how long it must be before the soul can learn to act under these limitations of time and space, and human nature; but I saw, also, that it MUST do it, - that it must make all this false true,- - and sow new and immortal plants in the garden of God, before it could return again. I saw there was no self; that selfishness was all folly and the result of circumstance; that it was only because I thought self real that I suffered; that I had only to live in the idea of the ALL, and all was mine. This truth came to me and I received it unhesitatingly; so that I was for that hour taken up into God. In that true ray most of the relations of earth seemed mere films, phenomena. (Steele 1992, pp. 10-11).

This account, which Fuller entered into her journal nine years later, represents what appears to have been a watershed moment in her emergent intellectual and spiritual life. Neither her burgeoning Romanticism nor the mainstream Unitarian disapproval of sudden conversion exemplified by Fuller's parents would have particularly inclined her to the sort of dramatic religious alteration that she seems to describe here. But it clearly made a lasting impression, relieving her of much of the pain and conflict that had afflicted her at that point in her life. In retrospect, this Thanksgiving Day experience seemed to have opened the floodgates of Fuller's spirituality, at once authorizing a heady new sense of spiritual independence and, at the same time, serving as a kind of personal touchstone for her later forays into other more occult realms of the spirit. In his discussion of this famous passage, Charles Capper identifies two overarching consequences that flowed from this episode: Fuller's embrace, first of all, of a new spirituality grounded in her own powerful intuition, and second, of a newly crystallized focus on the importance of self-transcendence (Capper 1992, p. 114).

It is certainly tempting to characterize this episode, as some critics have done, as a conversion experience-perhaps the first of several that Fuller experienced over the course of the next decade. Such a designation certainly makes sense, so long as we acknowledge that this was, once again, not a conversion experience centered on Christ, at least not ostensibly. Instead, as with Emerson's famous epiphany of the transparent eyeball, this experience took place, not in the church, but out of doors in the New England countryside. Furthermore, the essential insight that Fuller gains from this episode- "I saw there was no self; that selfishness was all folly ... that it was only because I thought self real that I suffered" - provides a radically fresh, if somewhat idiosyncratic, affirmation of the traditional Christian emphasis on self-denial as a prerequisite to saving grace. The parallel here to Emerson's famous transparent eyeball passage cited above is equally pronounced.

But whatever might have been the psycho-social pressures that precipitated the original experience or the literary associations of the passage she later drafted into her journal, it is clear that Fuller herself explicitly conceived her experience in religious, and again, like Emerson, even Pauline, terms: "This truth came to me, and I receive it unhesitatingly; so that I was for that hour taken up into God. In that true ray most of the relations of earth seemed mere films, phenomena" (2 Cor. 12.2). Indeed, in the 
months afterwards, she was not averse to employing Christian theological language to represent her experiences, but she now did so with a new sense of personal religious authority, as in this excerpt from an 1840 letter to William Henry Channing: "The old religionists did talk about "grace, conversion," and the like, technically, without striving to enter into the idea, till they quite lost sight of it. Undervaluing the intellect, they became slaves of a sect, instead of organs of the Spirit ... Yet the time seems now to have come for reinterpreting the old dogmas. I would now preach the holy Ghost as zealously as they have been preaching Man, and faith instead of the understanding, and mysticism \&c..." (Steele 1992, p. 14). By this point, a burgeoning religious confidence, not to say zeal, had come to supplant her former skepticism.

If the fall of 1831 marked the beginning of the first season of Fuller's religious awakening, the summer of 1840 apparently signaled the beginning of a second. By this point in time, Fuller and Emerson had become close friends and confidants, and while their friendship was at times mutually unsatisfying, Emerson admired her greatly for her learning and charisma, as she did him. In his recollections of Fuller posthumously included in the Memoirs, Emerson made particular mention of this spiritually formative period of her life:

I have alluded to the fact, that, in the summer of 1840, Margaret underwent some change in the tone and the direction of her thoughts, to which she attributed a high importance ... The literature of asceticism and rapturous piety was familiar to her. The conversation of certain mystics, who had appeared in Boston about this time, had interested her, but in no commanding degree. But in this year, 1840, in which events occurred which combined great happiness and pain for her affections, she remained for some time in a sort of ecstatic solitude. (Fuller 1852, vol. 1, p. 308).

For her part, Fuller herself alludes to this second season of awakening a couple of years later:

My inward life has been more rich and deep, and of more calm and musical flow than ever before. It seems to me that Heaven, whose course has ever been to cross-bias me, as Herbert said, is no niggard in its compensations ... But a new page is turned, and an era begun, from which I am not yet sufficiently remote to describe it as I would. I have lived a life, if only in the music I have heard, and one development seemed to follow another therein, as if bound together by destiny, and all things were done for me. All minds, all scenes, have ministered to me. Nature has seemed an ever-open secret; and the Divine, a sheltering love; truth, an always-springing fountain; and my soul more alone, and less lonely, more hopeful patient, and above all, more gentle and humble in its living ... (Fuller 1852, vol. 1, p. 310).

From the start, Margaret Fuller's accounts of her religious experiences were hardly normative in a Christian sense, less so perhaps even than Emerson's had been. Whatever the original substance of these early experiences, the ways in which she conceived of them reflected her astonishing erudition, her powerful religious imagination, and her ongoing life experience. In later years, her fascination with Greek mythology, mesmerism, spiritualism, and the occult, as well as her developing conceptions of women's special spiritual charisma, shaped her religious experiences and understandings in significant ways. However, at their inception, and even periodically thereafter, she, like Emerson, returned to tropes of self-emptying and self-transparency as the necessary precursors of supernatural inspiration, a pattern of construction with clear antecedents in her Puritan past, as we have seen (Steele 1992, pp. 146, 310, 309, 302).

\section{Born to Be a Pantheist}

From the standpoint of sales, Henry Thoreau must have considered the publication in 1849 of his first book $A$ Week on the Concord and Merrimack Rivers to be a disheartening setback, when four years after it first appeared, he finally gave in to his publisher's entreaties to accept the over 700 unsold copies still sitting in the warehouse, he noted wryly in his journal: "I have now a library 
of nearly 900 volumes, over 700 of which I wrote myself" (Thoreau 1981, vol. 7, p. 123). If the commercial result was disappointing, so too must have been its critical reception. Despite a few appreciative comments, several critics took issue with the book's ruminating argument, its apparent lack of structure, and perhaps above all, its ostensible pantheism and, at times, what some reviewers conceived as his saucy Orientalism. To the critic James Russell Lowell, Thoreau's warm embrace of whatever exotic Asian religious ideas seemed tasteless and disrespectful, and when his friend Horace Greeley later complained of the book's "defiant Pantheism," Thoreau simply responded that it could not be helped, since he "was born to be a pantheist" (Thoreau 1958, pp. 293-94). When readers today think of Thoreau in religious or spiritual terms, if they think of him in such terms at all, it is this portrait of a pantheist, nature worshipper, or heretic that is most likely to emerge. Indeed, of the three Transcendentalist writers profiled here, Thoreau seems at first blush the least apposite for the purposes of this study. Yet, even in this rather extreme case, Thoreau's several representations of heightened spiritual awakening, both in his journals and published writings, appear to draw on some of the same traditional tropes of self-emptying and self-transparency as did those of Emerson and Fuller, most notably in his characterizations of ecstatic self-reflexivity and witnessing.

Such avowed heterodoxy notwithstanding, Thoreau's early religious formation had been no less conventionally Unitarian, and perhaps in some respects even more conservative, than that of his contemporaries Fuller, Very, or even Emerson himself. After all, like his siblings, Thoreau had been born, baptized, and catechized under the watchful eye of Concord's conservative religious cleric, Ezra Ripley, and until his graduation from Harvard College in 1837, his religious views were still very much in keeping with those of the liberal wing of the Unitarian churches. Yet, notwithstanding this staid and rather conventional religious upbringing, by the time Thoreau asked to have his name removed from the membership rolls of Concord's First Parish Church at the age of twenty-two, he had also irretrievably and apparently quite painlessly shed most of the obvious trappings of the Christian faith, and from that point forward, set out to fashion an eclectic personal spirituality infused by his love of the natural world, his assimilation of Romantic ideas, and his immersion in world religions, Eastern as well as Western. In contrast to Very and Fuller, whose mature spirituality may be traced to one or another dramatic conversion-like experience, we find no such definitive religious break-through in Thoreau's early journals and letters. Instead, what we see are repeated references to early childhood experiences of a kind of euphoria or rapture in nature which continued in a somewhat abated form even into adulthood and which appear to have served as the chief inspiration for the formation of his distinctive and, to some, eccentric religious attitudes and experience.

The best record we have of Thoreau's burgeoning spiritual life is the Journal that he sedulously kept from 1837 until just a few months before his death in 1862, when it extended to some two million words. In the early years and throughout the decade of the 1840s, it served mainly as a repository for thoughts and reflections that he planned to draw upon for more formal compositions. By the summer of 1850, however, we see a conspicuous change in the character of Thoreau's journal entries, from the miscellany of poems and topical mini-essays of the early period to the more extended observations, lists, and reflections focusing on the natural world that characterize his later Journal. The Journal's transition from reflective miscellany to empirical record clearly has a bearing on our understanding of Thoreau's life and his changing sense of vocation, but it also sheds some light on his religious attitudes and experience. Early entries often give expression to experiences of peculiar rapture and exhilaration that took place during his frequent excursions outdoors. However, by the early 1850s, these expressions are often accompanied by a curious sense of nostalgia and regret. Thoreau drafted one of the most vivid of these into his Journal on July 16:

Formerly methought nature developed as I developed and grew up with me. My life was extacy. In youth before I lost any of my senses-I can remember that I was all alive-and inhabited my body with inexpressible satisfaction, both its weariness \& its refreshment were sweet to me. This earth was the most glorious musical instrument, and I was audience to its strains. To have such sweet impressions made on us—such extacies begotten of the breezes. 
I can remember how I was astonished, I said to myself-I said to others-There comes into my mind or soul an indescribable infinite all-absorbing divine heavenly pleasure, a sense of elevation \& expansion - and have had nought to do with it. I perceive that I am dealt with by superior powers. This is a pleasure, a joy, an existence which I have not procured myself-I speak as a witness on the stand and tell what I have perceived. The morning and the evening were sweet to me, and I lead a life aloof from society of men ... The maker of me was improving me. When I detected this interference I was profoundly moved. For years I marched as to a music in comparison with which the military music of the streets is noise \& discord. I was daily intoxicated and yet no man could call me intemperate. With all your science can you tell how it is—\& whence it is, that light comes into the soul? (Thoreau 1981, vol. 3, pp. 305-6).

I cite this poignant declaration at some length since it serves as a virtual compendium of several of the most distinctive features of Thoreau's personal religious and literary sensibility-the Wordsworthian sense of lost paradise, bodily wholeness, spiritual transport, and what he refers to here and elsewhere, following Emerson's own usage, as "extasy" (Hodder 2001).

However, unlike Emerson's more detached, philosophically invested notion of ecstasy, Thoreau's ecstasy is mediated by the body and senses. In fact, one cannot read far in the Journal, or for that matter Thoreau's published works, without recognizing the heights of rapture to which his sensory experience could sometimes lead-particularly certain forms of acoustic experience. Whether it be the song of the wood thrush, or the eerie other-worldly vibrations emitted by a newly erected telegraph wire, or the far-off sound of a drummer drumming in the night, to Thoreau's ears such seemingly extraneous sounds were quickly assimilated to music, and music to ecstasy:

The strains of the aeolian harp \& of the wood thrush are the truest \& loftiest preachers that I know now left on this earth-I know of no missionaries to us heathen comparable to them-They as it were, lift us up in spite of ourselves-They intoxicate they charm us. Where was that strain mixed into which this world was dropped but as a lump of Sugar to sweeten the draught. I would be drunk drunk drunk dead drunk to this world with it forever-He that hath ears let him hear The contact of sound with a human ear whose hearing is pure \& unimpaired is coincident with an extacy. (Thoreau 1981, vol. 7, p. 216).

The sacramental and even soteriological view Thoreau takes here of higher sensory experience clearly sets him off from most of his New England forebears, including his Transcendentalist friends themselves. For him, a cleansed and purified sense experience constitute the "divine germs" on which our future beatitude depends.

While the early Journal highlights a number of instances in which some stray natural sound or other lifts Thoreau to the pitch of ecstasy, he also exhibited a marked, at times almost preternatural, acuity to other forms of sensory experience as well, particularly sight. As readers of $A$ Week and Walden can readily confirm, Thoreau was especially captivated by the reflective properties of water-whether of willow trees on a riverbank, moonlight on a lake, or stars in a woodland stream-and his literary treatment of these visual experiences also sheds important light on the distinctive character of his religious thought and experience. His first book once again provides an early glimpse of the curious contemplative uses to which he was apt to put such visual perceptions:

It required some rudeness to disturb with our boat the mirror-like surface of the water, in which every twig and blade of grass was faithfully reflected; too faithfully indeed for art to imitate, for only nature may exaggerate herself. The shallowest still water is unfathomable. Wherever the trees and skies are reflected there is more than Atlantic depth, and no danger of fancy running aground. We noticed that it required a separate intention of the eye, a more free and abstracted vision, to see the reflected trees and the sky, than to see the river bottom merely; and so are there manifold visions in the direction of every 
object, and even the most opaque reflect the heavens from their surface. Some men have their eyes naturally intended to the one, and some to the other object. (Thoreau 1980, p. 48).

In this and related passages, the water serves as a vehicle of meditation and a test of the beholder's spiritual discernment, since a mere "separate intention of the eye" will lead to "manifold visions" and even an awareness of the descent of heaven on earth. More philosophically invested still is the famous related meditation on time in the "Where I Lived, and What I Lived For" chapter of Walden:

Time is but the stream I go a-fishing in. I drink at it; but while I drink I see the sandy bottom and detect how shallow it is. Its thin current slides away, but eternity remains. I would drink deeper; fish in the sky, whose bottom is pebbly with stars. I cannot count one. I know not the first letter of the alphabet. I have always been regretting that I was not as wise as the day I was born. (Thoreau 1971, p. 98).

Here, once again, a perception of reflections on water serves as the metaphorical vehicle for the vision that follows, but in this case, it precipitates a radically disjunctive existential alteration that unsettles the narrator's very sense of time and space, and returns him to a condition of childlike simplicity and unknowing. The figure governing both of these passages is of course the mirror, a trope that finds nearly universal expression in the contemplative traditions of the world, including the Christian Bible (1Cor. 13.12; 2 Cor. 3.18). Thoreau also found much to ponder in the mirror trope, since it was endlessly reproduced for him in one form or another everywhere in his own native landscape. In "The Ponds" chapter of Walden, for example, he lovingly compares the pond to "a perfect forest mirror" perpetually fresh, unstained, and sensitive to the atmosphere (Thoreau 1971, p. 188). But he was also apparently familiar with some of the more far-flung esoteric constructions where the mirror image and other metaphors of reflection serve to represent a process of self-realization, contemplative witnessing, and ecstasy. The classic expression of such ecstasy in Thoreau's writing, however, is the famous passage that occurs, fittingly enough, in the "Solitude" chapter of Walden:

With thinking we may be beside ourselves in a sane sense. By a conscious effort of the mind we can stand aloof from actions and their consequences; and all things, good and bad, go by us like a torrent. We are not wholly involved in Nature. I may be either the drift-wood in the stream, or Indra in the sky looking down on it. I may be affected by a theatrical exhibition; on the other hand, I may not be affected by an actual event which appears to concern me much more. I only know myself as a human entity; the scene, so to speak, of thoughts and affections; and am sensible of a certain doubleness by which I can stand as remote from myself as from another. However intense my experience, I am conscious of the presence and criticism of a part of me, which, as it were, is not a part of me, but spectator, sharing no experience, but taking note of it; and that is no more I than it is you. When the play, it may be the tragedy, of life is over, the spectator goes his way. It was a kind of fiction, a work of the imagination only, so far as he was concerned. This doubleness may easily make us poor neighbors and friends sometimes. (Thoreau 1971, pp. 134-35).

This curious passage, with its somewhat unsettling concluding admission, provides an even more developed meditation on the visual properties of reflections in a stream. It opens with a near verbal equivalent for the literal meaning of the term "ecstasy"—-to be "beside" oneself—but quickly qualifies this with the disclaimer "in a sane sense." The psychological, or better the contemplative, "doubleness" about which Walden's narrator speaks here is of course specifically related to the perceptual doubleness found in the related passages cited above. It is a defining feature of Thoreau's religious experience, and its pervasiveness throughout his writing suggests the higher spiritual significance it must have conveyed for him. The peculiar sense of doubleness that Thoreau evokes here, with its disorienting disjunction between the active self and the transcendental witness, maps comfortably onto the philosophical doubleness between understanding and Reason of which Emerson spoke in 1841, the disparate sense of self and All/God in Fuller's conversion narrative, and the "two consciousnesses" experienced by Very at the climactic stage of his Christian rebirth. 


\section{Concluding Reflections}

Apart from Thoreau, whose spiritual evocations in aggregate constitute something of an outlier to the group considered above, the earliest representations of religious experience provided by Emerson, Very, and Fuller often reflect, if only tangentially, their common biblical and liberal Christian background. Whether in Emerson's famously oracular non-sequitur "I am nothing, I see all," or Fuller's repudiation of "self" and "selfishness" in her deeply felt Thanksgiving Day epiphany, or Very's more orthodox-sounding account of conversion and rebirth penned to Henry Bellows, we hear clear echoes of the transformational movement from self-denial to spiritual fullness that lies at the heart of traditional Christian piety and seventeenth-century Puritan paradigms of conversion.

As for Thoreau, Christian narratives of faith appear to have left hardly a trace on his various evocations of ecstatic experience. This is not surprising in view of his early and unrepentant abandonment of the Christian faith. His was a spirituality grounded in the senses, inspired by the idioms of the natural world, and shaped by his study of Hindu sacred literature, in particular. Indeed, it may well be argued that a more proximate source for the peculiar form of ecstatic experience that we find expressed in Walden and other writings of his were certain classical Hindu texts, notably the Bhagavad Gita. Even so, the ecstatic self-displacement that accompanied his raptures in nature may find analogy, for example, in the contemplative quiet of the Quaker inner light and even the sort of spiritual self-emptying we see in the declarations of each of the contemporaries considered above. And while Thoreau's "ecstasies" were clearly mediated by sensory experience in ways that 'Emerson's apparently were not, Thoreau puts this term to similar Transcendentalist-inspired theological and contemplative uses, as in his famous conjuration of the reflections in a stream cited above. The unsettling experience of "doubleness" that results from such reflections is more psychologized perhaps than the metaphysical "double consciousness" that Emerson described in "The Transcendentalist" or the religious rebirth that Very recounted to Bellows or the contrast between the nothingness of the self and the totality of God evoked by Fuller, but the form and phenomenology of all four are similar.

One question that arises from such a demonstration is, of course, why? What would account for such formal similarities? For its part, this article has been mainly concerned with finding a historical basis for this pattern in the rhetorical development of early American religious discourse, from Puritan evangelicals, like Edwards, to Transcendentalists, like Emerson, Fuller, and Thoreau. However, in view of the apparently powerful, experientially sanctioned character of all these passages, it is tempting to posit some common spiritual substrate to which they might refer, notwithstanding apparent differences. For their part, the Transcendentalists themselves would no doubt readily assent to such an interpretive move, insofar as one of their major contributions to the history of American religious thought was their influential advocacy of an emphatic early form of religious universalism and perennialism. Time and place may change, they would argue, the details of history and culture may vary, but such peak religious experiences were at heart perennially the same the world over. Thoreau spoke for most when in Walden, he wrote:

The solitary hired man on a farm in the outskirts of Concord, who has had his second birth and peculiar religious experience, and is driven as he believes into silent gravity and exclusiveness by his faith, may think it is not true; but Zoroaster, thousands of years ago, travelled the same road and had the same experience; but he, being wise, knew it to be universal, and treated his neighbors accordingly, and is even said to have invented and established worship among men. (Thoreau 1971, p. 141).

It is certainly the case that the writers considered above would have conceived their various episodes of heightened religious experience explicitly in universalist and perennialist terms, particularly as they became better acquainted with Asian religious and philosophical sources after the late-1830s and during the decade of the 1840s. Nevertheless, the particular rhetorical form in which they presented them-the sharply paradoxical "I am nothing, God is all" that we noted for example in the early writings of Emerson and Fuller, and even in more displaced forms in Thoreau-continues 
to bear the distinctive stamp of an older Christian sensibility and style. This is not, by any means, to discount the important religious eclecticism and cosmopolitanism of the Transcendentalists; it is simply to highlight a continuity of religious language and usage from Puritans to Transcendentalists that has gone mostly unremarked.

By the same token, despite apparent continuities and parallels, we also note a good deal of variation and apparent divergence in the ways each of these writers elaborated on their extraordinary experiences originally and in subsequent years. By 1841, the sometimes biblically inflected declarations of Emerson's sermons and early lectures gave way to his more classic affirmations of the apotheosis of the "Self" and "Oversoul." We know little, on the other hand, of Jones Very's religious development after the religious crisis of 1838 that precipitated his dramatic season of awakening and his remarkable outpouring of poems, but there is no reason to believe that he conceived it outside the pale of the more traditionally recognizable paradigms of Christian rebirth that he evoked in his poems and his letter to Bellows. For her part, Margaret Fuller's religious experiences, as they evolved, were both more dynamic and more difficult to characterize in institutionally recognizable ways. Here too, the impact of the Christian milieu in which she was raised is apparent in the language of her early journal entries, but Christian and biblical sources apparently failed to gain much traction once she attempted to come to terms with the rich and varied experiences that animated her subsequent spiritual life. For these, she turned increasingly to the idioms of nineteenth-century feminism, mesmerism, and the occult. As for Thoreau, after the resurgence of ecstatic evocations of the early 1850s, his journal apparently goes increasingly silent in this regard and is given over instead to the meticulous recording of seasonal changes in flora and fauna surrounding his Concord home. In short, in viewing the expressions of these Transcendentalists' religious experience as a whole, we are as much struck by the variations and change in the literary record, as by the affinities, parallels, and continuities.

Conflicts of Interest: The author declares no conflict of interest.

\section{References}

Bellah, Robert, Richard Madsen, William M. Sullivan, Ann Swidler, and Steven M. Tipton. 1985. Habits of the Heart: Individualism and Commitment in American Life. Berkeley: University of California Press.

Brooks, Van Wyck. 1936. The Flowering of New England, 1815-1865. New York: E. P. Dutton.

Capper, Charles. 1992. Margaret Fuller: An American Romantic Life: The Private Years. New York: Oxford UP.

Chauncy, Charles. 1743. Seasonable Thoughts on the State of Religion in New England. Boston: Rogers and Fowle, p. 327.

Cole, Phyllis. 2002. Mary Moody Emerson and the Origins of Transcendentalism: A Family History. Oxford: Oxford University Press.

Deese, Helen R. 1993. Introduction. In Jones Very: The Complete Poems. Edited by Helen R. Deese. Athens: University of Georgia Press, pp. xi-lv.

Edwards, Jonathan. 1995. A Jonathan Edwards Reader. Edited by John Smith, Harry S. Stout and Kenneth P. Minkema. New Haven: Yale University Press.

Emerson, Ralph Waldo. 1939. The Letters of Ralph Waldo Emerson. Edited by Ralph L. Rusk, George Salter and Eleanor M. Tilton. New York: Columbia University Press.

Emerson, Ralph Waldo. 1957. Selections from Ralph Waldo Emerson. Edited by Stephen E. Whicher. Boston: Houghton Mifflin.

Emerson, Ralph Waldo. 1965. Journals and Miscellaneous Notebooks. Edited by William H. Gilman, Alfred R. Ferguson, George P. Clark, Merrell R. Davis, Merton M. Sealts, Ralph H. Orth, A. W. Plumstead, Hayford Harrison, William H. Parsons, Ruth H. Bennett and et al. Cambridge: Harvard University Press.

Emerson, Ralph Waldo. 1971. Collected Works of Ralph Waldo Emerson. Edited by Alfred R. Ferguson and Robert E. Spiller. Cambridge: Harvard University Press.

Emerson, Ralph Waldo. 1992. The Complete Sermons of Ralph Waldo Emerson. Edited by Albert J. von Frank, Ronald A. Bosco, Teresa Toulouse, Andrew H. Delbanco and Wesley T. Mott. Columbia: University of Missouri Press. 
Fuller, Margaret. 1852. The Memoirs of Margaret Fuller Ossoli. 2 vols; Edited by James Freeman Clarke, W. H. Channing and Ralph Waldo Emerson. London: R. Bentley.

Gittleman, Edwin. 1967. Jones Very: The Effective Years, 1833-1840. New York: Columbia University Press.

Grodzins, Dean. 2010. Unitarianism. In The Oxford Handbook of Transcendentalism. Edited by Joel Myerson, Sandra Harbert Petrulionis and Laura Dassow Walls. Oxford: Oxford University Press, pp. 50-69.

Gura, Philip K. 2007. American Transcendentalism: A History. New York: Farrar, Straus, and Giroux.

Hodder, Alan D. 1991. "After a High Negative Way": Emerson's 'Self-Reliance' and the Rhetoric of Conversion. Harvard Theological Review 84: 423-46. [CrossRef]

Hodder, Alan D. 2001. Thoreau's Ecstatic Witness. New Haven: Yale University Press.

Howe, Daniel Walker. 1970. The Unitarian Conscience: Harvard Moral Philosophy, 1805-1861. Middletwon: Wesleyan University Press.

Hutchison, William R. 1959. The Transcendentalist Ministers: Church Reform in the New England Renaissance. New Haven: Yale University Press.

Miller, Perry. 1956. From Edwards to Emerson. In Errand into the Wilderness. Cambridge: Harvard University Press. First published 1940.

Packer, Barbara L. 2007. The Transcendentalists. Athens: University of Georgia Press.

Parrington, Vernon Louis P. 1927. Main Currents in American Thought. New York: Harcourt.

Richardson, Robert D., Jr. 1995. Emerson: The Mind of Fire. Berkeley: University of California Press.

Robinson, David. 1975. Jones Very, the Transcendentalists, and the Unitarian Tradition. Harvard Theological Review 68: 103-24. [CrossRef]

Robinson, David. 1982. Apostle of Culture: Emerson as Preacher and Lecturer. Philadelphia: University of Pennsylvania Press.

Rusk, Ralph L. 1949. The Life of Ralph Waldo Emerson. New York: Charles Scribner's.

Steele, Jeffrey, ed. 1992. The Essential Margaret Fuller. New Brunswick: Rutgers University Press.

Thoreau, Henry David. 1958. The Correspondence of Henry David Thoreau. Edited by Walter Harding and Carl Bode. New York: New York University Press.

Thoreau, Henry David. 1971. Walden. Princeton: Princeton University Press.

Thoreau, Henry David. 1980. A Week on the Concord and Merrimack Rivers. Princeton: Princeton University Press. Thoreau, Henry David. 1981. Journal. Edited by Elizabeth Hall Witherell, William L. Howarth, Robert Sattelmeyer, Thomas Blanding, Mark R. Patterson, William Rossi, Patrick F. O'Connell, Heather Kirk Thomas, Nancy Craig Simmons, Ron Thomas and et al. Princeton: Princeton University Press.

Very, Jones. 1993. Jones Very: The Complete Poems. Edited by Helen R. Deese. Athens: University of Georgia Press. Wright, Conrad. 1955. The Beginnings of Unitarianism in America. Boston: Starr King Press, p. 3 ff. 